\title{
Metrik Pertumbuhan Organisasi Pada Permainan Hay Day
}

\author{
Muhammad Yusril Fakkaruddin 1,*, Ardisca Evanandy², Muhammad Ali Zamroni ${ }^{3}$, Muhammad \\ Ainul Yaqin ${ }^{4}$
}

Jurusan Teknik Informatika, Universitas Islam Negeri Maulana Malik Ibrahim, Indonesia

${ }^{1}$ yusrilfakarudin@gmail.com; ${ }^{2}$ ardisca99@gmail.com; ${ }^{3}$ zroni4@gmail.com; ${ }^{4}$ yaqinov@ti.uin-malang.ac.id

* corresponding author

INFO ARTIKEL

Riwayat Artikel

Diterima: 23 Desember 2020

Direvisi: 15 Januari 2020

Diterbitkan: 30 April 2020

\section{ABSTRAK}

Organisasi merupakan suatu kelompok yang terdiri dari sekumpulan orang dalam satu wadah untuk mencapai tujuan bersama. Suatu Organisasi dapat dikatakan berkembang apabila memenuhi beberapa aspek contohnya seperti struktur organisasi dan proses bisnis yang dijalankan. Pada penelitian ini kami menggunakan studi kasus pada permainan Hay Day yang bertujuan untuk mencari pertumbuhan organisasi pada permainan Hay Day dimana pada permainan Hay Day semakin bertambahnya level maka struktur organisasi dan proses bisnis yang dijalankan semakin besar. Maka dari itu pengukuran dilakukan berdasarkan level sebagai parameter variabel bebas kemudian mencari metric kompleksitas pada struktur Organisasi yang telah dibentuk. Pengukuran dibentuk menggunakan pemodelan pada model proses bisnis dimana perhitungan tersebut memiliki kemiripan dalam menghitung notasi-notasi tiap tingkatan. Selanjutnya Metode perhitungan yang digunakan yaitu dengan menggunakan metode perhitungan graf. Kemudian yatiu melakukan perhitungan dengan metode regresi untuk menemukan pertumbuhan dari struktur organisasi pada permainan Hay Day. Hasil perhitungan dari regresi linier menunjukkan bahwa pengukuran pertumbuhan struktur organisasi pada permainan Hay Day diperoleh R2 bernilai 97,8\%.

\section{PENDAHULUAN}

Organisasi merupakan sekumpulan kelompok orang yang bekerja sama secara sistematis, terencana, terpimpin, terkendali, dalam pemanfaatan sumber daya manusia (SDM) dan sumber daya alam yang digunakan secara efisien dan efektif agar tercapainya tujuan dari Organisasi. Adapun faktor-faktor dari pertumbuhan organisasi antara lain pembentukan struktur organisasi, penentuan job description, pembuatan standar operasional prosedur (SOP), dan pembuatan model proses bisnis. Tujuan Organisasi berdiri adalah menghasilkan keuntungan. Selain menghasilkan keuntungan hal penting yang harus suatu organisasi perhatikan adalah meningkatkan pertumbuhan organisasi sehingga menjadi lebih baik dan besar. Pada dasarnya, pertumbuhan organisasi dapat terbentuk suatu struktur yang menjadikan sebuah pondasi terbentuknya organisasi seperti halnya struktur organisasi. Selain itu, pertumbuhan organisasi tidak terlepas dari kelangsungan hidup dan profitabilitas suatu organisasi. Oleh karena itu, struktur organisasi didesain dengan baik untuk sebuah organisasi yang efektif yang mana dengan adanya sumber daya manusia dalam organisasi perusahaan struktur organisasi dapat diimplementasikan sesuai sistem kerja organisasi untuk tujuan organisasi yang efektif dan efisien [1]. Efektivitas Organisasi merupakan tingkat ketepatan pencapaian suatu sasaran dengan memanfaatkan sumber daya-sumber daya yang ada [2].

Kompleksitas struktur organisasi merupakan penggambaran dari tingkat diferensiasi. Diferensiasi horisontal memperhatikan tingkat sejauh mana pekerjaan tersebar secara geografis, Diferensiasi vertikal merujuk pada kedalaman organisasi dandiukur dengan cara 
menghitung jumlah tingkatan hierarki suatu organisasi [6]. Kompleksitas struktur organisasi dapat diukur dengan berbagai macam metrik pemodelan kompleksitas proses bisnis karena strukturnya notasinya hampir sama. Pada penelitian Corti menggunakan metrik BPMN untuk mengukur notasi proses bisnis [5]. Coskun menggukanan CADAC (Cognitive Activity Depth Arc Control Flow) Metrik untuk mengukur notasi-notasi model proses bisnisnya [4].

Pada paper ini, kasus yang akan diselesaikan adalah pertumbuhan organisasi pada permainan Hay Day. Game ini bertema keluarga dan santai yang dimana memperkenalkan sebuah kiat-kiat menjadi petani, peternak, dan pengusaha yang sukses. Pada permainan ini pemain akan mengalami berbagai proses bisnis pada tiap level. Tiap bertambahnya level maka bertambahnya pula proses bisnis yang akan dilakukan dimana struktur organisasinya akan semakin kompleks dikarenakan makin banyaknya fitur dan aktifitas yang ada didalamnya. Sehingga permasalahan yang akan dibahas ialah untuk mengetahui pengaruh dari struktur organisasi terhadap tingkat keefektivitas organisasi berdasarkan kompleksitas struktur organisasinya.

Dalam beberapa tahap untuk mewujudkan tujuan paper ini adalah mengidentifikasi metrik, merepresentasi metrik, memformulasikan metrik dan memvalidasi metrik. Metode identifikasi yang digunakan adalah metode Goal Question Metric (GQM). Paper ini mengidentifikasi bahwa metrik untuk sebuah organisasi Struktur Organisasi dan Proses bisnis. Dari beberapa formula kompleksitas yang sudah pernah diajukan, kami menambahkan perhitungan terhadap kompleksitas struktur organisasi dengan menggunakan perhitungan Graph. Hasil kompleksitas kemudian dihitung menggunakan metode regresi untuk mencari kurvanya. Untuk formulasinya, Paper ini menggunakan metode Analytical Hierarchy Process (AHP).

\section{METODE}

Pada penelitian sebelumnya [3], skema pertumbuhan organisasi dipresentasikan berdasarkan proses bisnisnya menggunakan notasi BPMN, kemudian mengukur skala kompleksitasnya berdasarkan: Level, Node Size, Arc Size, Elements, CFC, Scale. Selanjutnya diukur menggunakan metode regresi. Kemudian, pengaruh struktur organisasi dengan dimensi yang terdiri dari variabel kompleksitas (X1), formalisasi (X2), sentralisasi (X3) secara simultan dan secara parsial terhadap efektivitas organisasi (Y) [1]. Sehingga pada paper tersebut, peneliti menghitung pertumbuhan struktur organisasinya dimana kami menghitung kompleksitasnya berdasarkan:

$\begin{array}{ll}\text { Scale } & : \text { Skala kompleksitas } \\ \mathrm{n} & : \text { Banyaknya simpul atau node } \\ \mathrm{e} & : \text { Banyaknya garis, dimana e=n-1 } \\ \text { Average Depth } & : \frac{(\text { Level 1*n Level 1)+(Level 2*n Level 2)+(Level 3*n Level 3)+(Level n*n Level } \mathrm{n})}{n} \\ \text { weight } & : \text { Jumlah daun (leaf) }\end{array}$

Kemudian setelah menghitung kompleksitasnya, kami menghitung pertumbuhannya juga dengan menggunakan metode regresi linier.

\section{Identifikasi Dengan GQM}

Pendekatan Goal Question Metrics (GQM) digunakan untuk mengembangkan model karena pendekatan ini memungkinkan penggunaan model untuk ditingkatkan setiap saat [7]. GQM menggunakan format standar untuk menjelaskan pengukuran dan kepada siapa pengukuran ini berlaku[8]. Langkah pertama, atribut model dimasukkan ke dalam 
tujuan. Kedua, pertanyaan dirancang untuk menilai tujuan yang telah ditentukan pada langkah pertama. Terakhir, seperangkat metrik dikembangkan untuk memberikan informasi dalam menjawab pertanyaan [7]. Adapun hasil identifikasi metrik menggunakan GQM dapat dilihat pada Tabel 1. Hasil identifikasi memperoleh bahwa metrik yang akan digunakan adalah Node, Edge, Average Depth, Weight, Scale

Tabel 1. Hasil Identifikasi Metrik Menggunakan GQM

\begin{tabular}{lll}
\hline & Tujuan & Mengajukan \\
Goal & Isu & Formula yang komprehensif dan sensitif terhadap \\
& perubahan kecil \\
& Objek & Formula kompleksitas Struktur Organisasi \\
& Sudut Pandang & Manajer Proyek \\
\hline Question & Apa yang membentuk sebuah Organisasi? \\
Metrics & Struktur Organisasi, Job Description, SOP, Proses \\
& Bisnis \\
\hline Question & Apa saja metrik pertumbuhan organisasi yang pernah \\
Metrics & diajukan? \\
& Level, Node Size, Arc Size, Elements, CFC, Scale. \\
\hline Question & Pada Proses Bisnis \\
Metrics & Apa saja metrik pertumbuhan organisasi yang belum \\
& diajukan? \\
& Node, Edge, Average Depth, Weight pada Struktur \\
\hline
\end{tabular}

\section{Representasi Struktur Organisasi Level 1-5}

Metrik yang telah diidentifikasi selanjutnya direpresentasikan menggunakan model Graph. Dimana terdapat Node, Edge, Depth, Weight, dan Scale yang akan direpresentasikan ke dalam metrik, kemudian digunakan sebagai pengukuran terhadap AHP. Adapun struktur organisasi level 1-5 dapat dilihat pada Gambar 1 hingga Gambar 5.

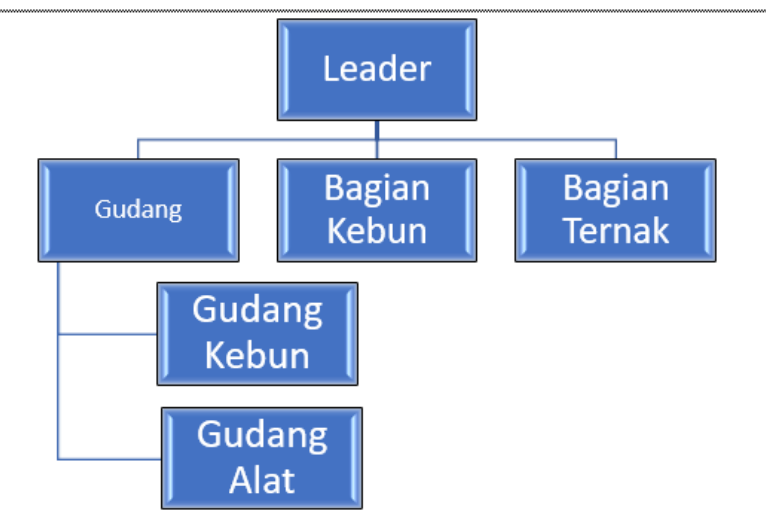

Gambar 1. Struktur Organisasi pada Level 1

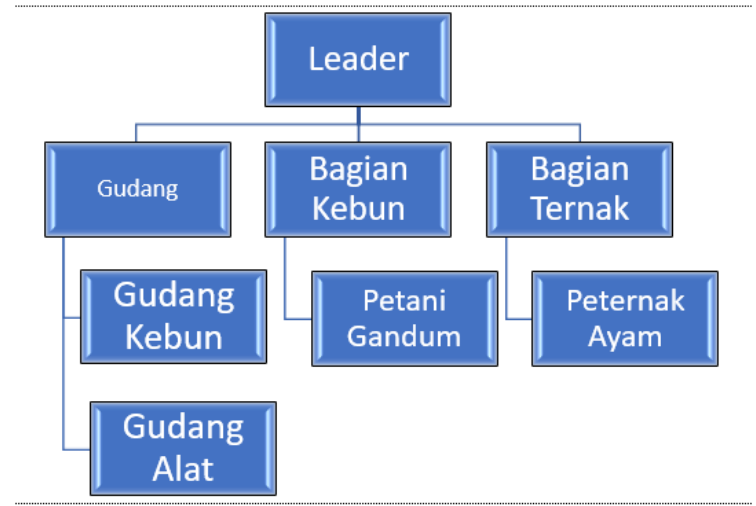

Gambar 2. Struktur Organisasi pada Level 2 


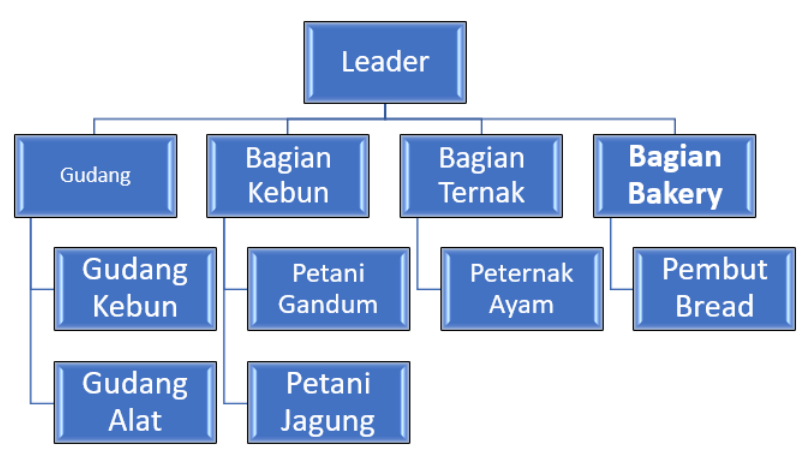

Gambar 3. Struktur Organisasi pada Level 3

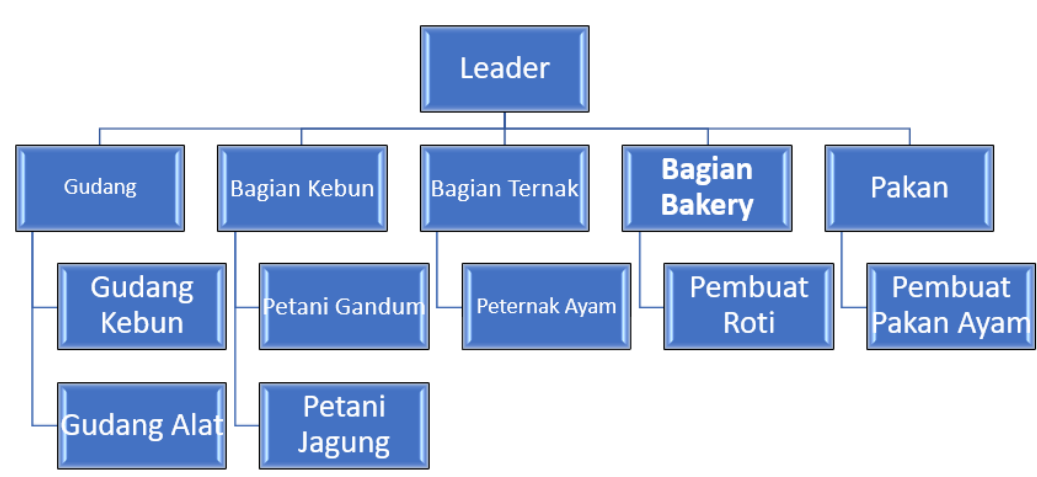

Gambar 4. Struktur Organisasi pada Level 4

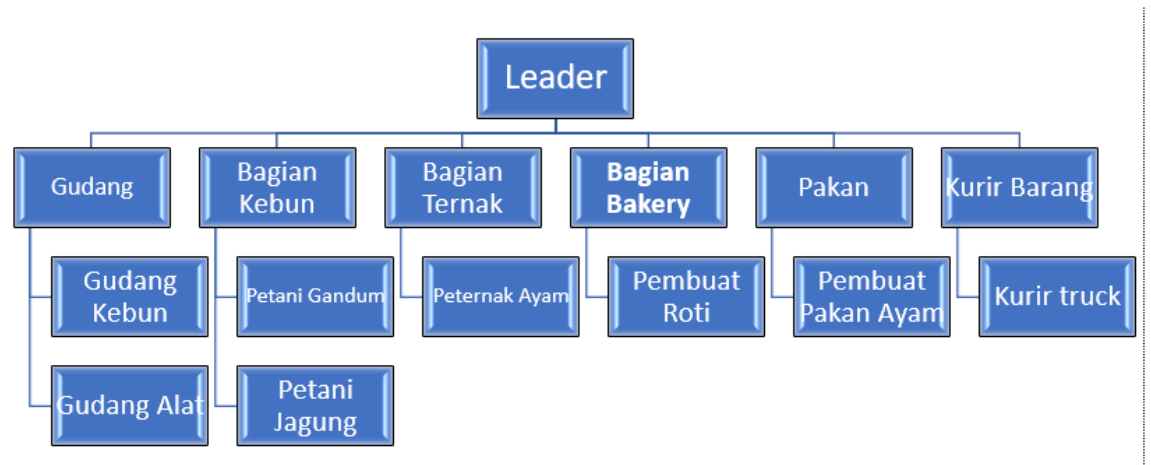

Gambar 5. Struktur Organisasi pada Level 5

\section{Formulasi Metrik menggungakan metode AHP}

Untuk menghitung bobot menggunakan metode AHP, pertama yaitu menentukan parameter input pada struktur organisasi, dimana parameter yang ditentukan meliputi Node, Edge, Average Depth, dan Weight. Berikut adalah hasil dari penentuan parameter struktur organisasi mulai dari level 1 sampai 10 pada Tabel 2. Setelah ditentukan parameternya, selanjutnya perhitungan AHP, didapatkan hasil bobot pada Tabel 3 berikut.

Tabel 2. Input setiap metrik dari Struktur Organisasi

\begin{tabular}{ccccc}
\hline Level & Node (n) & Edge (e) & $\begin{array}{c}\text { Average } \\
\text { Depth }\end{array}$ & Weight \\
\hline 1 & 6 & 5 & 2.16 & 4 \\
2 & 8 & 7 & 2.37 & 4
\end{tabular}




$\begin{array}{ccccc}3 & 11 & 10 & 2.45 & 6 \\ 4 & 13 & 12 & 2.46 & 7 \\ 5 & 15 & 14 & 2.47 & 8 \\ 6 & 19 & 18 & 2.52 & 11 \\ 7 & 26 & 25 & 2.57 & 16 \\ 8 & 28 & 27 & 2.57 & 17 \\ 9 & 32 & 31 & 2.59 & 20 \\ 10 & 35 & 34 & 2.62 & 23\end{array}$

Tabel 3. Bobot setiap metrik Struktur Organisasi

\begin{tabular}{lc}
\hline \multicolumn{1}{c}{ Metrik } & Bobot \\
\hline A. Node & 0.5 \\
B. Edge & 0.23 \\
C. Average Depth & 0.17 \\
D. Weight & 0.1
\end{tabular}

\section{HASIL DAN PEMBAHASAN}

\section{Perhitungan Skala kompleksitas Struktur Organisasi}

Pada prosedur perhitungan, untuk mencari kompleksitasnya dilakukan penentuan skala (scale) dimana dalam menentukannya parameter yang digunakan ialah input dari setiap metrik struktur organisasi (Tabel 2) dan bobot hasil dari perhitungan AHP (Tabel 3). Hasil perhitungan menggunakan rumus di bawah ini dapat dilihat pada Tabel 4 dan grafik kompleksitas dapat dilihat pada Gambar 6.

Scale $=A * n+B * e+C *$ average depth $+D^{*}$ weight

$\begin{array}{ll}\text { Scale } & : \text { Skala kompleksitas } \\ \mathrm{n} & : \text { Banyaknya simpul atau node } \\ \mathrm{e} & : \text { Banyaknya garis, dimana } \mathrm{e}=\mathrm{n}-1\end{array}$

Average Depth $\frac{:(\text { Level } 1 * \mathrm{n} \text { Level } 1)+(\text { Level } 2 * \mathrm{n} \text { Level } 2)+(\text { Level } 3 * \mathrm{n} \text { Level } 3)+(\text { Level } \mathrm{n} * \mathrm{n} \text { Level } \mathrm{n})}{n}$

weight :Jumlah daun (leaf)

Tabel 4. Perhitungan Kompleksitas Struktur Organisasi

\begin{tabular}{cccccc}
\hline Level & A*Node (n) & B*Edge (e) & $\begin{array}{c}\text { C*Average } \\
\text { Depth }\end{array}$ & D*Weight & Scale \\
\hline 1 & 3 & 1,15 & 0,37 & 0,4 & 4,92 \\
2 & 4 & 1,61 & 0,40 & 0,4 & 6,41 \\
3 & 5,5 & 2,3 & 0,42 & 0,6 & 8,82 \\
4 & 6,5 & 2,76 & 0,42 & 0,7 & 10,38 \\
5 & 7,5 & 3,22 & 0,42 & 0,8 & 11,94 \\
6 & 9,5 & 4,14 & 0,43 & 1,1 & 15,17 \\
7 & 13 & 5,75 & 0,44 & 1,6 & 20,79 \\
8 & 14 & 6,21 & 0,44 & 1,7 & 22,35 \\
9 & 16 & 7,13 & 0,44 & 2 & 25,57 \\
10 & 17,5 & 7,82 & 0,45 & 2,3 & 28,07
\end{tabular}




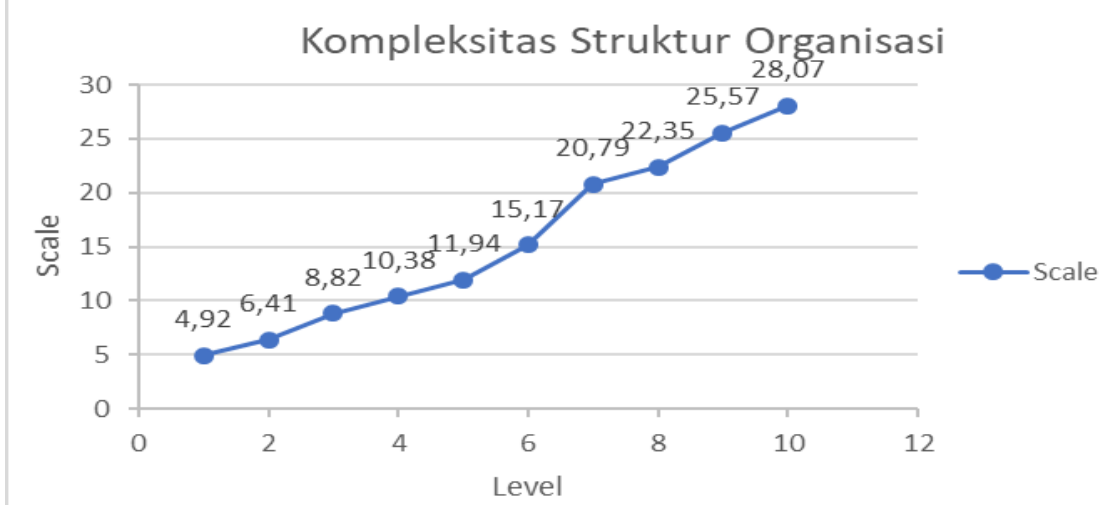

Gambar 6. Grafik Kompleksitas Struktur Organisasi

\section{Pengujian Regresi}

Grafik regresi linear dapat dilihat pada Gambar 7. Perhitungan regresi dilakukan dengan menggunakan metode regresi linier untuk menghitung pengaruh skala dari struktur organisasi terhadap pertumbuhan setiap level.

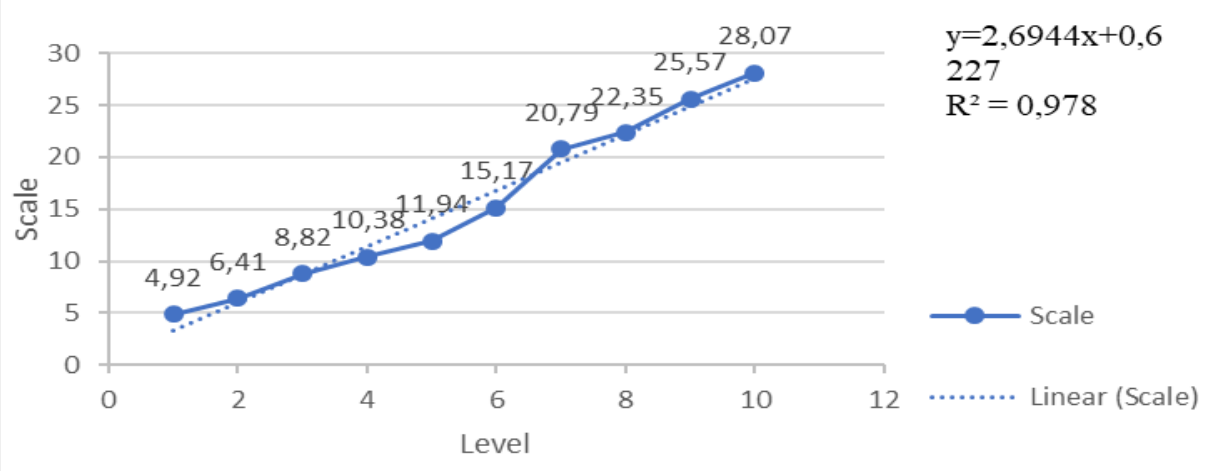

Gambar 7. Grafik Regresi Linier

\section{Analisis Regresi Linier}

Koefisien regresi kompleksitas (X) sebesar 2,6944 (Gambar 7), menunjukkan besarnya pengaruh dari kompleksitas struktur organisasi terhadap efektivitas organisasi, dan koefisien regresi bertanda positif menunjukkan bahwa kompleksitas berpengaruh searah terhadap efektivitas organisasi, yang berarti setiap peningkatan level maka meningkat pula jumlah skala kompleksitasnya (Tabel 3), sehingga akan menyebabkan peningkatan keefektivitas organisasi yang menandakan bahwa organisasi tersebut tumbuh (Gambar 6).

Kemudian menghasilkan sebuah $\mathrm{R}^{2}$ sebesar 0,978, artinya bahwa 97,8\% variable efektivitas organisasi dipengaruhi oleh variabel kompleksitas $\mathrm{X}$, sisanya efektivitas organisasi dipengaruhi oleh variabel bebas yang tidak dibahas atau diperhitungkan pada paper ini, seperti Standar Operasional Prosedur (SOP) dan Proses Bisnis.

\section{KESIMPULAN}

Pertumbuhan Organisasi dapat diukur dari struktur organisasi yang semakin berkembang setiap levelnya sehingga dapat dicari kompleksitasnya sehingga akan membentuk suatu keefektivitas organisasi. Setelah diketahui skala kompleksitasnya, kemudian dilakukan penghitungan dengan menggunakan metode regresi linier. Hasil perhitungan bahwa pada Gambar 7 dihasilkan $\mathrm{R}^{2}$ bernilai 97,8\% menunjukkan bahwa kompleksitas $\mathrm{X}$ pada regresi linier memiliki pengaruh besar terhadap efektivitas organisasi yang berarti setiap peningkatan level maka meningkat pula jumlah skala kompleksitasnya 
(Tabel 3), sehingga akan menyebabkan peningkatan keefektivitas organisasi yang menandakan bahwa organisasi tersebut tumbuh.

\section{REFERENSI}

[1] Gammahendra, F. (2014). Pengaruh struktur organisasi terhadap efektivitas organisasi (studi pada persepsi pegawai tetap Kantor perwakilan Bank Indonesia Kediri). Jurnal Administrasi Bisnis, 7(2).

[2] Mohyi, A. (2012). Teori dan Perilaku Organisasi: Membentuk, mengelola, mendeteksi kepribadian, efektivitas dan mengembangkan organisasi. Malang: UMMPress.

[3] Yaqin, M. A., Majid, M., Fradana, F. F., \& Mustofa, M. R. (2019). Pertumbuhan Model Proses Bisnis Pada Permainan Hay Day Menggunakan Metode Regresi. Prosiding SENIATI, 42-49.

[4] Çoşkun, E. M. R. İ. Y. E. (2014). A New Complexity Metric for Business Process Models. Master. Atilim University, 80.

[5] Corti, C. (2012). BPMETRICS: a software system for the evaluation of some metrics for business process.

[6] Robbins, S. P. (1994). Teori organisasi: struktur, desain dan aplikasi. Jakarta: Arcan.

[7] Rizawanti, R., \& Arthana, I. K. R. (2019). Usability Testing Pada Aplikasi Hooki Arisan Dengan Model PACMAD Menggunakan Pendekatan GQM. KARMAPATI (Kumpulan Artikel Mahasiswa Pendidikan Teknik Informatika), 8(1), 33-42.

[8] Aeni, K. (2018). EVALUASI SISTEM INFORMASI AKADEMIK DENGAN GQM UNTUK DOKUMEN TATA LAKSANA MANAJEMEN INSIDEN. Jurnal Penelitian dan Pengabdian Kepada Masyarakat UNSIQ, 5(1), 14-23. 